\title{
Application of the Delayed Royalty Framework for Onshore Petroleum Investment in Nigeria Using the 1993 Production Sharing Contract
}

\author{
Frank Egede ${ }^{1}$, Oghenerume Ogolo ${ }^{2}$, Salihu Ayuba ${ }^{3}$, Victor Anochie $^{4}$, Hezekiah Agogo ${ }^{5}$, \\ Amina Danmadami ${ }^{6}$, Zephaniah Ajibade ${ }^{7}$ \\ ${ }^{1,7}$ Petroleum Training Institute, Effurun \\ ${ }^{2,3}$ Nile University of Nigeria, Abuja \\ 4,5 Baze University, Abuja \\ ${ }^{6}$ Department of Petroleum Resources, Abuja
}

\begin{abstract}
The 1993 production sharing contract (PSC) in Nigeria specifies different royalty rates for oil and gas investment. The royalty rates were fixed. This makes the fiscal arrangement to be regressive in nature. Royalty rate of $20 \%$ is to be paid for onshore investment using the 1993 PSC. Hence, there is a need to make the fiscal arrangement progressive. The delayed royalty framework was incorporated into the1993 PSC as a progressive measure to make it dynamic. Two economic models were developed using spreadsheet technique to evaluate the impact of the delayed royalty framework on onshore petroleum investment. The 1993 PSC fiscal framework was used to develop the economic models. The delayed royalty framework was incorporated into one of the models. The delay in royalty payment hinged on the payout period of the investment. It was observed that the delayed royalty framework increased the contractor's revenue during the period of low oil price. Thus, increasing the sustainability of the investment during period of low oil price.
\end{abstract}

KEYWORD: Delayed Royalty Framework, Economics, Petroleum Investment, Royalty, Sustainability.

\section{INTRODUCTION}

The recent pandemic caused by Corona Virus Disease 2019 (COVID-19) has necessitated the need for oil and gas producing Nations to adjust their fiscal regime to attract petroleum investments and increase the chance of sustainability of oil and gas companies during periods of low oil price. Adjusting the petroleum fiscal regime may include introducing incentives to foster oil and gas investments and making the fiscal regime more progressives (Echendu et al., 2015; Johnston, 1994). This can be done by making the host government to surrender part of her economic rents (Iledare, 2004). Echendu and Iledare, (2016) described a progressive fiscal regime as one that allows the host government of oil and gas producing nations to surrender part of her economic rents such as royalty, tax, production bonuses etc. Petroleum fiscal system becomes attractive to oil and gas companies when the host government give up some economic rent during harsh conditions.

Nigeria is the $9^{\text {th }}$ producer of oil in the world and has an oil reserves of over 36 billion barrels. Though the country plans to increase her reserve to 40 billion barrels of oil in 2025. Nigeria currently uses the two types of petroleum fiscal system based on location. The concessionary fiscal system is used for onshore investment, while the contractual petroleum fiscal system is used for off shore investment. Over the years, there have been several fiscal regime adopted for petroleum investment in the country. The following fiscal arrangement have been used in Nigeria; the 1969 Petroleum Act, 1993 production sharing contract, deep offshore and inland basin production sharing contact amendment act and petroleum industry act. Though for about two decades, Nigeria tried to reform her petroleum sector up until 2021 (Iledare, 2010; Nwosi-Anele et al., 2018; Nyoor et al., 2019). The passage of the petroleum industry act in 2021 was a great mile stone for the country. The royalty framework in the PIA 2021 is progressive in nature and slides based on terrain, production and oil price.

It was observed that the royalty specification for onshore investment in some of the fiscal arrangement that have been used in the country was regressive in nature. The regressive nature of these fiscal regime and the need to attract more investment in the petroleum sector prompted a change of the fiscal regimes. The concessionary petroleum fiscal system in the 1993 production sharing contract is seen to be regressive in nature as a result of the fixed royalty rate specified for onshore investment. It is also perceived to be high as well. Royalty rate of $20 \%$ was specified for onshore investment. Echendu and Iledare (2016) investigated the impact 


\section{International Journal of Current Science Research and Review}

ISSN: 2581-8341

\section{Volume 05 Issue 02 February 2022}

DOI: 10.47191/ijesrr/V5-i2-24, Impact Factor: 5.825

IJCSRR @ 2022

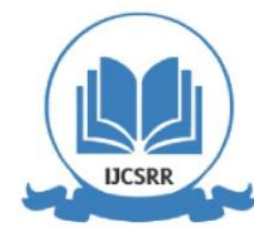

WwW.ijcsrr.org

of the progressive royalty framework in Nigeria using the royalty framework in the petroleum industry bill (PIB) 2009. They recommended the usage of the sliding scale royalty payment as a bidding parameter. The sliding scale royalty makes a fiscal system progressive in nature, and it should be used also as an economic rent instrument.

Ogolo and Nzerem, (2021) proposed the delayed royalty framework for upstream petroleum investment. The delayed royalty framework was seen as a tool that can be used to make a petroleum fiscal system progressive. The delay in royalty payment was hinged on the time it takes the contractor to recoup his capital. The delayed royalty framework helps to increase the chances of E\&P company sustainability during period of low oil price. It can be used to also make a petroleum fiscal system attractive. The delayed royalty framework is based on the concept that royalty payments will be made after the contractor has recoup his capital. This research therefore investigated the application of a delayed royalty framework for onshore investment in Nigeria using the 1993 PSC fiscal arrangement.

\section{MATERIALS AND METHODS}

Spreadsheet modelling technique was used to evaluate the economic viability of onshore petroleum investment using the 1993 PSC fiscal arrangement (Echendu et al., 2014; Echendu et al., 2015; Echendu et al., 2018). This technique enables the usage of the net cash flow (NCF) equation where in the production data from a field is used as the source of revenue (Jahn et al., 2008; Ileadare, 2017; Mian, 2002). Equation one shows the typical NCF equation (Ogolo et al., 2020). Royalty payments and technical cost are usually deducted from the gross revenue before the calculation of taxable income. The NCF obtained from the investment is used to calculate other profitability indicators.

$$
\text { NCFt }=\text { GRt }- \text { ROYt }- \text { CAPEXt }- \text { OPEXt }- \text { BONUS }- \text { TAXt }- \text { OTHERt }
$$

In this research, two petroleum economic models were built for petroleum investment in onshore Nigeria using the 1993 PSC fiscal arrangement. One of the models had a fixed royalty rate and it was termed as Scenario 1. While the other model had a delayed royalty framework. The second model was termed as Scenario 2. The delay in royalty payment was hinged on the fact that the contractor will only make payment of royalty until he has recoup his initial capital for the investment. Oil price was varied in the models from $\$ 30-\$ 90 /$ bbl. Profitability indicators used to access the viability of this fiscal instrument include: NPV (Net present value) and payout period. The decline curve analysis was used to model the production of oil from a typical onshore field in Nigeria. Table 1 shows the economic assumptions and fiscal terms used to build the economic models.

Table 1: Economic Assumptions and Fiscal Terms

\begin{tabular}{|l|l|l|}
\hline Item & Value & Unit \\
\hline Exploration Cost & 80 & \$MM/year \\
\hline Exploration Years & 2 & Years \\
\hline Field Development & 2 & Years \\
\hline Development Cost-Year 1 & 800 & $\$$ MM \\
\hline Development Cost-Year 2 & 550 & $\$$ MM \\
\hline Production begins in & 4 & Years \\
\hline Initial Production & 1500 & BOPD \\
\hline OPEX & 5 & $\%$ \\
\hline Oil Price & $30-90$ & $\$ / \mathrm{bbl}$ \\
\hline Royalty rate & 20 & $\%$ \\
\hline Depreciation (SLD) & 5 & Year \\
\hline Discount rate & 10 & $\%$ \\
\hline Income tax rate & 85 & $\%$ \\
\hline NDDC LEVY & 3 & $\%$ \\
\hline Education Tax & 2 & $\%$ \\
\hline
\end{tabular}

*SLD - Straight Line Depreciation 


\section{International Journal of Current Science Research and Review}

ISSN: 2581-8341

Volume 05 Issue 02 February 2022

DOI: 10.47191/ijcsrr/V5-i2-24, Impact Factor: 5.825

IJCSRR@ 2022

Www.ijcsrr.org

\section{RESULTS AND DISCUSSION}

\section{Profitability Analysis of the Investment}

Figure 1 shows the yearly royalty payment obtained from the two scenarios. Scenario 1 had no delay in the royalty payment but Scenario 2 had a delay in the royalty payment. The delay in the royalty payment is clearly seen in Scenario 2 . The royalty payment in this scenario began after some years. Payment of royalty was made after the contractor has recoup his capital. The delayed royalty framework was incorporated into the model as a function of the time it takes the contractor to recoup his cost of investment. When the oil price was $\$ 30 / \mathrm{bbl}$, the royalty payment in Scenario 2 began in year 13 . While when the oil price was $\$ 90 / \mathrm{bbl}$, payment of royalty began in year 9 . But for Scenario 1, the royalty payment began during the beginning of field oil production. It was also observed that the higher the oil price, the higher the royalty payment made. The higher the oil price, the lower the delay in royalty payment.

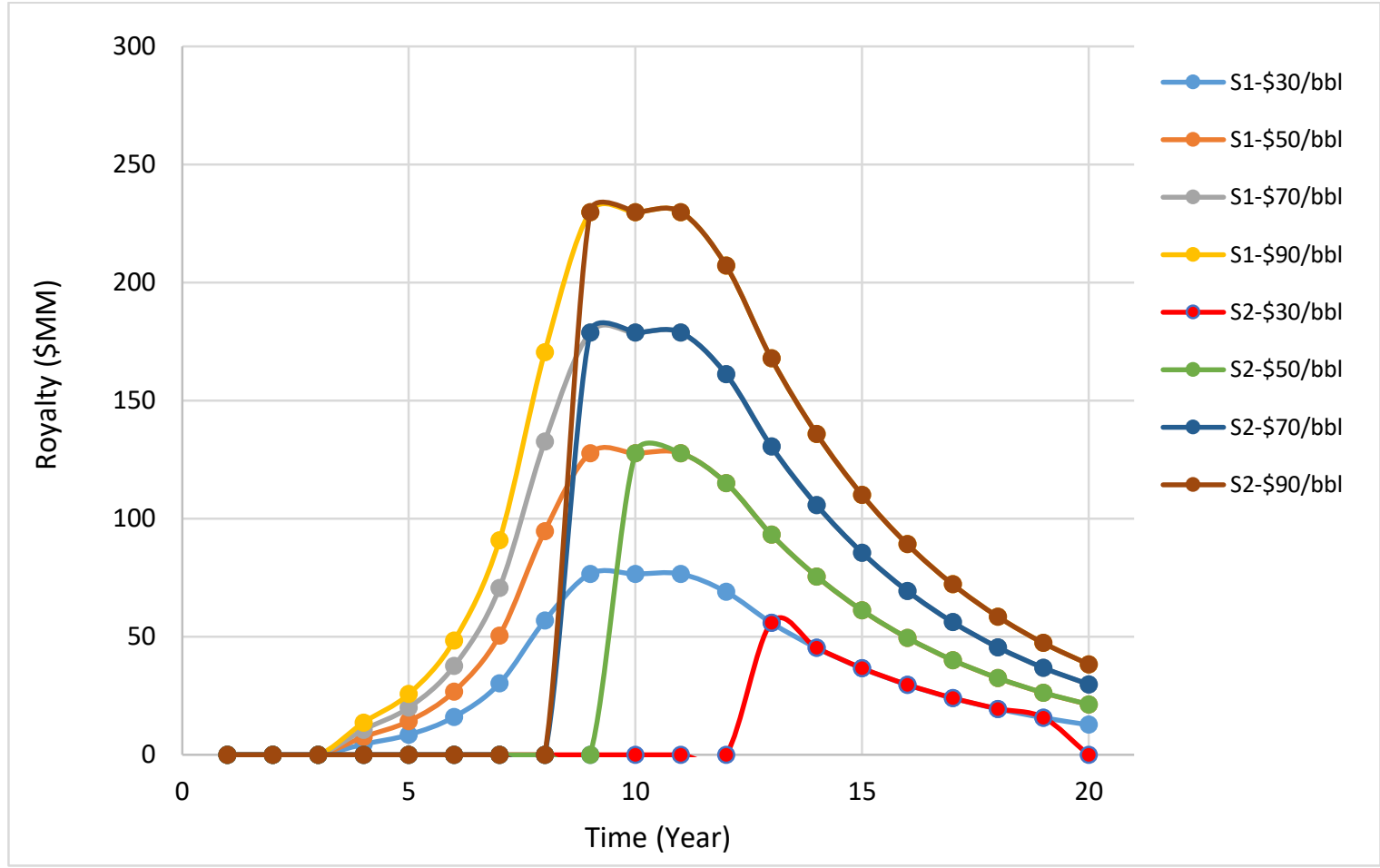

Figure 1: Yearly Royalty Payment from Scenario 1 and Scenario 2

Figure 2 shows the host government NPV obtained from Scenario 1 and Scenario 2. It is seen that the host government NPV obtained from Scenario 1 was higher that the host government NPV obtained from Scenario 2. This was due to the delay in the royalty payment imposed in Scenario 2. The host government NPV for Scenario 1 when the oil price was $\$ 30 / \mathrm{bbl}$ and $\$ 90 / \mathrm{bbl}$ were about \$226.7 MM and \$2042.3 MM. While the host government NPV for Scenario 2 when the oil price was \$30/bbl and \$90/bbl were $\$ 119 \mathrm{MM}$ and \$2002.9 MM. The higher the oil price, the higher the host government NPV. The same observation was also seen in the contractor's NPV as shown in Figure 3. The higher the oil price, the higher the contractor's NPV. The NPV obtained from both Scenarios were negative until an oil price of $\$ 90 / \mathrm{bbl}$. It seen the delayed royalty framework help to increase the contractor's revenue from the investment. The NPV of the contractor obtained from Scenario 1 and Scenario 2 when the oil price was $\$ 30 / \mathrm{bbl}$ were $\$ 408 \mathrm{MM}$ and $-\$ 300 \mathrm{MM}$. When the oil price was \$90/bbl, the NPV of the contractor became about \$43.6 MM and 83.6 MM. 


\section{International Journal of Current Science Research and Review}

ISSN: 2581-8341

Volume 05 Issue 02 February 2022

DOI: 10.47191/ijesrr/V5-i2-24, Impact Factor: 5.825

IJCSRR@ 2022

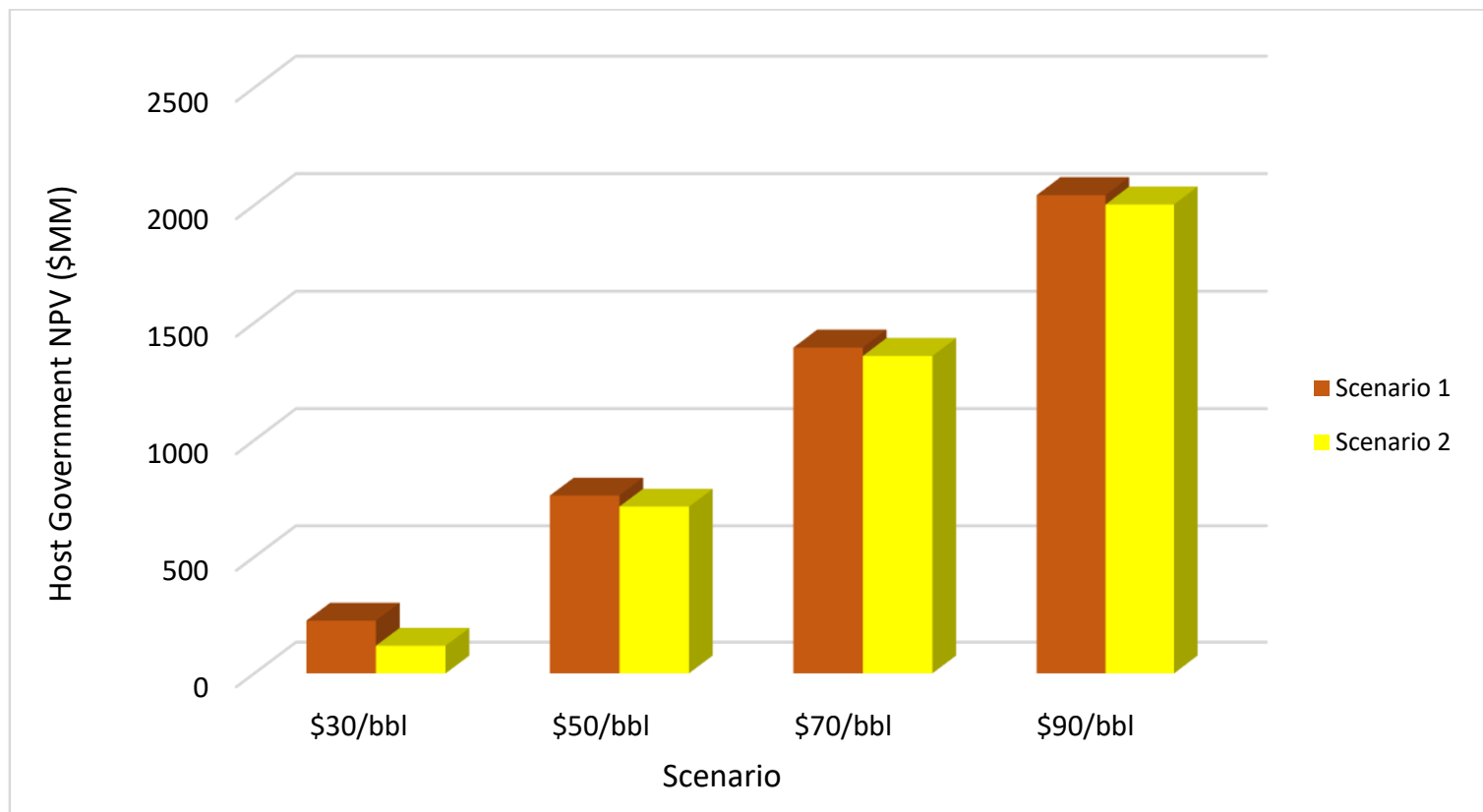

Figure 2: Host Government NPV from Scenario 1 and Scenario 2

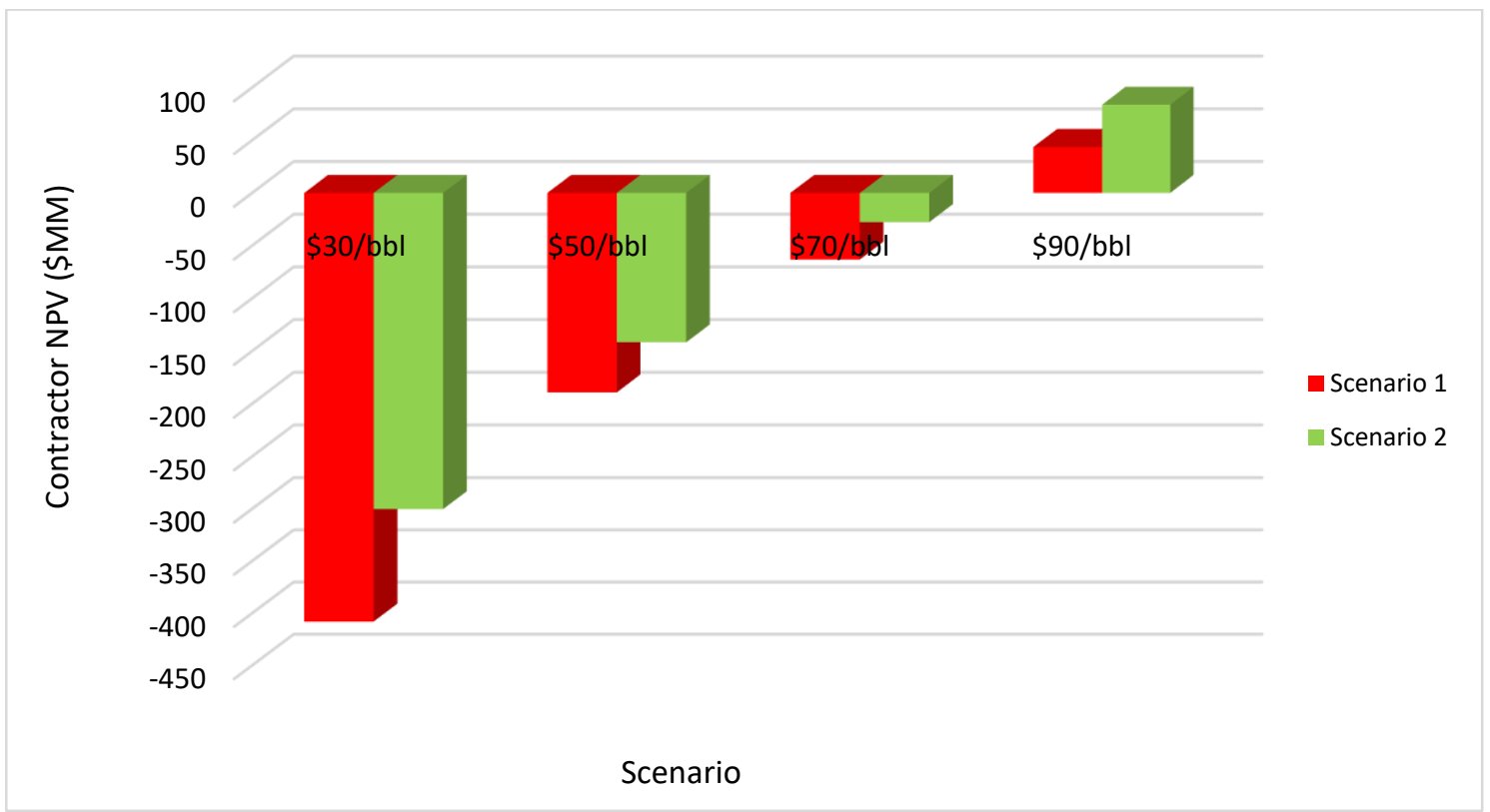

Figure 3: Contractor's NPV from Scenario 1 and Scenario 2

The payout period of the investment obtained from both scenarios is shown in Figure 4. It is seen the delay in royalty payment caused a reduction in the payout period thus increasing the sustainability of the investment. At an oil price of $\$ 30 / \mathrm{bbl}$, the investment was not profitable using Scenario 1 but the delay in the royalty payment observed in Scenario 2 made the investment to be profitable leading to a payout period of about 13 years. The higher the oil price, the higher the payout period obtained from both Scenarios. Though the payout period obtained from Scenario 1 was higher than the payout period obtained from Scenario 2 . This was due to the delayed royalty framework imposed in Scenario 2. 


\section{International Journal of Current Science Research and Review}

ISSN: 2581-8341

Volume 05 Issue 02 February 2022

DOI: 10.47191/ijesrr/V5-i2-24, Impact Factor: 5.825

IJCSRR@ 2022

www.ijcsrr.org

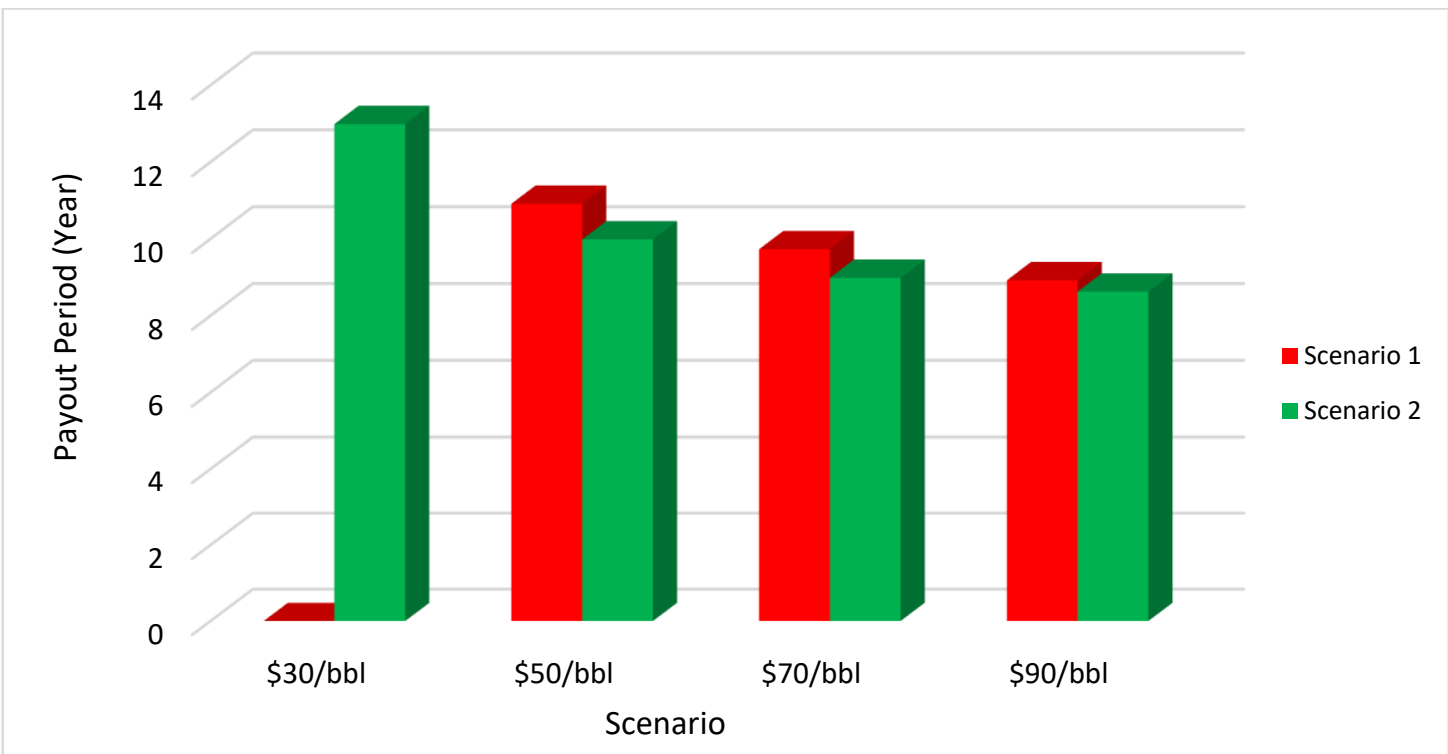

Figure 4: Payout period from the Scenario 1 and Scenario 2

\section{CONCLUSION}

- The delayed royalty framework increased the contractor's NPV obtained from the investment and reduced the host government revenue. This will enable the contractor to have more money to cushion some of the effect of low oil price. The higher the oil price, the more favorable the delayed royalty framework as the contractor will recoup his capital early during the investment.

- The delayed royalty framework helps to increase the sustainability of the investment during periods of low oil price. At an oil price of \$30/bbl, the investment was not sustainable and the contractor could not recoup his capital. But with the delayed royalty framework, the payout period of the investment was about 13 years.

- The delayed royalty framework could also be applied to marginal field investment to encourage and sustain indigenous companies in the oil industry.

\section{REFERENCES}

1. Echendu, J. C., Iledare, O. O., Akinlawon, A. J., \& Idowu, A. J. (2018). Replacing Petroleum Profit Tax with a Dual Petroleum Tax System: Implication on Petroleum Project Economics in Nigeria. SPE Nigeria Annual International Conference and Exhibition. doi:10.2118/193453-ms.

2. Echendu, J. C., Iledare, O. O., \& Onwuka, E. I. (2015). Comparative Economic-Performance Analysis of ProductionSharing Contracts in Angola, Equatorial Guinea, Gabon, and Nigeria. SPE Economics \& Management, 7(04), 157166. doi:10.2118/162990-pa.

3. Echendu J. C and Iledare O. O. (2016). Progressive Royalty Framework for Oil- and Gas-Development Strategy: Lessons From Nigeria. SPE Econ. \& Manag. 8(03), 68-77. doi:10.2118/174846-pa.

4. Echendu, J. C., Onwuka, E. I. \& Iledare, O. (2014). Spreadsheet Modeling and Simulation Analysis of Production Sharing Contract Terms and Instruments in Nigeria. SPE Nigeria Annual International Conference and Exhibition, Lagos, 5-7 August. SPE-172389-MS http://dx.doi.org/10.2118/172389-MS.

5. Iledare, O. O. (2004). Analyzing the Impact of Petroleum Fiscal Arrangements and Contract Terms on Petroleum E\&P Economics and the Host Government Take SPE Nigeria Annual Technical Conference and Exhibition, Abuja, Nigeria, 24 August. SPE-88969-MS. http://dx.doi.org/10.2118/88969-MS.

6. Iledare, O. O. (2010). Evaluating the Impact of Fiscal Provisions in the Draft Petroleum industry Bill on Offshore E\&P Economics and Take Statistics in Nigeria. 34th Annual SPE International Conference and Exhibition, Tinapa-Calaba, Nigeria, 31 July-7 August. SPE-136972-MS. http://dx.doi.org/10.2118/136972-MS. 


\section{International Journal of Current Science Research and Review}

ISSN: 2581-8341

Volume 05 Issue 02 February 2022

DOI: 10.47191/ijesrr/V5-i2-24, Impact Factor: 5.825

IJCSRR@ 2022

Www.ijcsrr.org

7. Iledare, O. O. (2017). Advanced Petroleum Economics. Lecture Note, African University of Science and Technology, Abuja, Nigeria.

8. Johnston, D. (1994). International Petroleum Fiscal Systems and Production Sharing Contracts, pp. 25. Tulsa, USA: PennWell Publishing Company.

9. Jahn, F. Cook, M. \& Graham, M. (2008). Petroleum Economics. In F. Jahn, M. Cook \& M. Graham (Eds), Hydrocarbon Exploration and Production (pp. 337-364). Oxford: Elsevier.

10. Mian, M. A. (2002). Project Economics and Decision Analysis, Vol. 1. PennWell Corporation.

11. Nyoor, B., Oyebimpe, A., \& Iledare, O. O. (2019). The Impact of the Proposed Petroleum Industry Fiscal Bill PIFB, 2018 Tax Scheme on the Economics of Oil Production in Nigeria. SPE Nigeria Annual International Conference and Exhibition. doi:10.2118/198782-ms.

12. Nwosi-Anele, A. S., Adeogun, O., \& Iledare, O. (2018). Analysis of Government and Contractor Take Statistics in the Proposed Petroleum Industry Fiscal Bill. SPE Nigeria Annual International Conference and Exhibition. doi:10.2118/193470-ms

13. Ogolo, O., \& Nzerem, P. (2021). A delayed royalty framework for investments in the exploration and production of hydrocarbon. Petroleum Research. doi:10.1016/j.ptlrs.2021.04.004.

14. Ogolo, O. Nezrem, P., Iledare, O. O., Okafor, S. I., Iloegbunam, E., Ekeoma, P. I. (2020). Assessing the Impact of Deep Offshore and Inland Basin Production Sharing Contract Amendments on the Economics of Deep Offshore E\&P Assets in Nigeria. SPE Nigeria Annual International Conference and Exhibition.. doi.org/10.2118/203741-MS

15. Oyekunle, A. A. (2011). Impact of the Petroleum Industry Bill on Deepwater Economics. Nigeria Annual International Conference and Exhibition. doi:10.2118/150774-ms.

Cite this Article: Frank Egede, Oghenerume Ogolo, Salihu Ayuba, Victor Anochie, Hezekiah Agogo, Amina Danmadami, Zephaniah Ajibade (2022). Application of the Delayed Royalty Framework for Onshore Petroleum Investment in Nigeria Using the 1993 Production Sharing Contract. International Journal of Current Science Research and Review, 5(2), 514-519 